\title{
Geoenvironments from the vicinity of Arctowski Station, Admiralty Bay, King George Island, Antarctica: vulnerability and valuation assessment
}

\author{
Carlos Ernesto G. R. Schaefer, ${ }^{1}$ Rogério Mercandelle Santana, ${ }^{1}$ Felipe Nogueira Bello Simas, ${ }^{2}$ Márcio R. \\ Francelino, ${ }^{3}$ Elpídio Inácio Fernandes Filho, ${ }^{1}$ Miriam Abreu Albuquerque, ${ }^{2}$ and Maria Lúcia Calijuri ${ }^{4}$ \\ ${ }^{1}$ Departamento de Solos - Universidade Federal de Viçosa, Av. PH Rolfs s/n, Viçosa, 36570-000, Minas Gerais, Brazil (carlos.schaefer@ufv.br) \\ ${ }^{2}$ Centro Universitário de Caratinga, BR-116, KM-526, Caratinga, MG, 35300-930, Brazil (fsimass@yahoo.com.br; miralbuq@funec.br) \\ ${ }^{3}$ Instituto de Florestas - Universidade Federal Rural do Rio de Janeiro, BR 465 km 7, Seropédica, 23890-000, Rio de Janeiro, Brazil \\ (marciorocha@uffrj.br) \\ ${ }^{4}$ Departamento de Engenharia Civil - Universidade Federal de Viçosa, Av. PH Rolfs s/n, Viçosa, 36570-000, Minas Gerais, Brazil (calijuri@ufv.br)
}

\begin{abstract}
The use of a geographic information system (GIS) allows the mapping and quantification of biotic and physical features of importance to the environmental planning of Antarctic areas. In this paper we examined the main aspects of the geoenvironments of Arctowski Station vicinity (Admiralty bay, Maritime Antartica), by means of a photointerpretation of an orthomosaic at 1:6000 scale, produced by non-conventional aerial photographs obtained by the Brazilian Cryosols project. We carried out a preliminary environmental valuation and vulnerability assessment of the area. Hence, geoenvironments were classified and ranked according with their biological valuation and vulnerability (fragility), mapping 20 units covering approximately 150 ha. The most fragile geoenvironmental units were former and present penguin rookeries with different vegetation covers, all very prone to degradation by over-trampling and human perturbations. The relationships between each geoenvironment were also explored, emphasizing the ecological aspects and their valuation. In quantitative terms, the most vulnerable and fragile units (classes 4 and 5) occupy nearly $22 \%$ of the total area, being highly concentrated near the coastal areas. There, ornithogenic input is an important factor favoring the vegetation development.

Citation: Schaefer, C. E. G. R., Santana, R. M., Simas, F. B., Francelino M. R., Fernandes Filho, E. I., Albuquerque, M. A., and Calijuri, M. L. (2007), Geoenvironments from the vicinity of Arctowski Station, Admiralty Bay, King George Island, Antarctica: vulnerability and valuation assessment, in Antarctica: A keystone in a Changing World - Online Porceedings of The ISAES, edited by A.K. Cooper and C.R. Raymond et al., USGS Open-File Report 2007-1047, Short Research Paper 015, 4 p.; doi:10.3133/of2007-1047.srp015.
\end{abstract}

\section{Introduction}

Detailed mapping of Antarctic geoenvironments are scanty, due to unavailability of good resolution aerial photographs or images to carry out the studies at an appropriate scale. The Cryosols project in the Brazilian Antarctic program has developed a platform for a Hasselbladd camera in a helicopter, allowing excellent high resolution photos to be obtained. The mosaics produced were then used for mapping the physical and biological environment with high quality products of low cost (Santana, 2006).

Landscape is a natural resource and therefore a variable to be considered in landscape planning decisions (Dearden, 1985). A structured method of landscape assessment, linking description, classification, analysis and evaluation, provides an integrated framework within which decisions on land management and advice can be debated (Cooper and Murray, 1992).

The terrestrial environments of ice-free ground of Admiralty Bay, King George Island, are dominated by cryosols covered by a cryptogamic flora, composed mostly by lichens, algae and mosses; only two native flowering plants are present, Deschampsia antarctica (Poaceae), and Colobanthus quitensis (Caryophillaceae).

Studies performed by the Polish and Brazilian scientists in Maritime Antarctica have demonstrated that P-rich guano leachates strongly react with the underling bedrock, forming a layer of phosphatized material that can be subdivided into genetic horizons of different mineral composition (Tatur \& Barczuc, 1983; Tatur \&
Myrcha, 1993). On these sites, a true oasis of vegetation cover develops, where one can observe greater biological activity, higher temperature and thicker active layer.

Vegetation development in ice free soils of Admiralty Bay appears to be highly fragile, and influenced by biogenic inputs of marine origin, either promoted by birds or mammals, increasing the plant community diversity in limited areas. However, due to the intense periglacial dynamic, the degree of landform stability should also be taken into consideration, as erosive processes, especially gelifluction, greatly affect plant communities in the region.

According to Walton (1984) there is a need for integrated biological, pedological and geomorphological studies in the Antarctic Peninsula, not yet fulfilled to this day. This clearly requires the integrated interpretation of biological data combined with edaphic and landforms studies, to fill the gap in knowledge of assessing the vulnerability (fragility) and valuation (biological value) of Maritime Antarctica landscapes, preferentially using a GIS based system. It is hoped that this integrated analysis will contribute to the permanent environmental monitoring of the area under the influence of Polish and Brazilian research activities.

\section{Material and methods}

Admiralty Bay is located in King George Island, part of the South Shetlands Archipelago, Maritime Antartica (Figure 1). This climatic zone is characterized by higher mean air temperatures and higher liquid water availability when compared to other climatic zones of Antarctica. 
According to data sets from 1982-2002, acquired in the Brazilian Comandante Ferraz Station, the mean air temperature varies from $-6.4{ }^{\circ} \mathrm{C}$ in July to $2.3{ }^{\circ} \mathrm{C}$ in February. Positive air temperatures are observed from November until March. Mean annual precipitation is $366.7 \mathrm{~mm}$. During the last decade a mean temperature increase of 0.2 to $0.6{ }^{\circ} \mathrm{C}$ has been registred and is a possible reason for the evident retreat of the glaciers in this period in Admiralty Bay (Rakusa-Suszczewski, 1993).

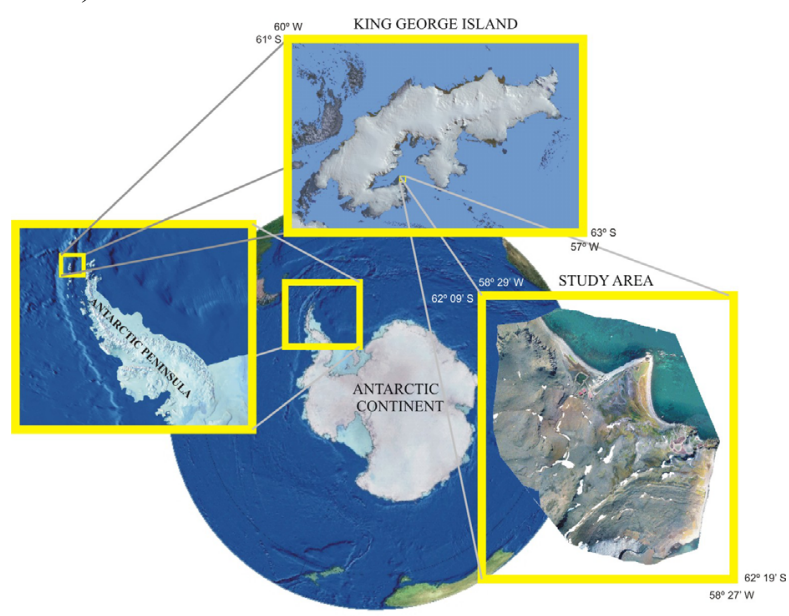

Figure 1. Location of the study area.

The soils and plants were collected on the Western coast of Admiralty Bay, on the surroundings of the Polish Henry Arctowski Station and inside the Antarctic Specially Managed Area (ASPA) No. 128. The studied area is of volcanic origin and the soils are developed mainly from Tertiary tholeiite basalts and glacial till.

Landforms and vegetation types described in this work were extensively observed and investigated both in the field and from photointerpretation of high quality aerial photographs obtained in the summer 2002/2003, at 1: 6000 scale. Photographs were obtained by an adapted submetric Hasselblad camera mounted under the helicopter cabin. Subsequently, a mosaic of photographs was produced and georeferenced by DGPS control points. All maps were verified in the following summer (2003/2004), allowing adjustments to be made to the originals. Twenty geoenviromental units were identified and mapped (Table 1).

Numerous techniques of landscape evaluation have been devised (Crofts and Cooke, 1974). In this work, we used qualitative approaches focused upon the evaluation of ecological complexity of landscape using the perception of experts (Daniel and Vining ,1983; Orland et al. 1995), and quantitative approaches such as those which measure physical and aesthetic characteristics of the visual field directly. Reliability depends on the consistency and accuracy of the individual applying the method as the assessments are usually carried out by an "ecological expert" (Daniel and Vining, 1983). The vulnerability classes of each geoenvironment were defined and ranked (between 1-5) according with wellestablished soil, geomorphological and biological attributes. The environmental valuation was based on the degree of uniqueness and biomass and biodiversity of each vegetation/soil type. Where snow cover was present, it was classified as an independent unit, as it was virtually impossible to infer the underlying geomorphological/pedological and biological features.

\section{Results and discussion \\ Vegetation communities}

To the northwest of Ecology Glacier (Figure 2), 15 ha of Cryosols are strongly affected by nesting activities of penguins and other birds. These form the most fragile geoenvironments of this area, with outstanding value. Plant communities of ice-free areas are constituted predominatly by lichens, mostly Usnea Antarctica (Du Rietz) and U. aurantiaco-atr (Jacq.) Bory in well drained sites; bryophytes, of which Sanionia uncianata (Hedw.) has the greatest biomass of all, occurs in virtually all types of moss-dominated soils. In ill-drained areas, also, cyanobacteria are commonly observed forming mats on fine sediments around melting channels and lakes. Amongst the macroscopic green algal, the ornithocoprophilous Prasiola crispa commonly occurs in ornithogenic sites, whereas P. cladophylla (Carmich.) Menegh is occasionally observed, being restricted to melting water channel. Lichenized fungi are found in virtually all environments, presenting the greatest plant diversity. Flowering plants are represented solely by Deschampsia antarctica Desv. and Colobanthus quitensis (Kunth) Bartl., as well as the invader Poa annua, which grows associated with mosses and fruticose liches, forming coalesced assemblages commonly observed on ornithogenic soils, fairly phosphatized. All plants are very prone to disturbance, and were classified as very (4) and extremely (5) vulnerable and fragile.

The evaluation of plant communities distribution is particularly important for the study of dynamics and ecological relations with abiotic factors (such as soils, rock, and landforms). A more precise quantification can also assist to estimate trends in $\mathrm{C}$ stocks of the terrestrial ecosystems of Antarctica, under the influence of global warming.

The total extent of vegetation cover is approximately $21 \%$ of the total area, summing up 32 ha (Table 1), and is highly concentrated in the lower coastal areas (Fig. 2). Plant communities occur either as homogeneous stands (lichens and moss turf) or as mixed formations. Bryophytes and lichens accounts for more than $13 \%$ of all vegetation types, and the most important are moss turfs, such as Sanionia uncinata (Hedw.) Loeske, Warnstorfia sarmentosum (Wahlenb.) Hedenäs, Tortula spp. and Bryum spp., and Usnea antarctica. Stands of Deschampsia antarctica Desv. and Colobanthus quitensis (Kunth) Bartl only occur in association with lower plants, 
due to the earlier successional stage found in this part,

Locally, Deschampsia antarctica is abundant in and around nesting areas, whilst Colobanthus quitensis is still infrequent, consistent with the observation of Zarycky (1993) in the ASPA 128 of Admiralty Bay. Rock outcrops with nitrofilic lichens Penguin Rookeries, Mosses carpets and Vegetated Protalus were among the most fragile and valued geoenvironment, due to their uniqueness and sensitivity to disturbance.

The relationship between plant communities' development and nesting areas is directly related to nutrient bioavailability during the initial stages of succession, in which $\mathrm{P}$ and $\mathrm{N}$ levels are still limiting. However, the vegetation appears to follow the installation of nests. This is particularly the case of Skuas nest, which presents greater localized nutrient level than neighboring, non-ornithogenic areas (Schaefer et al. 2004). On the other hand, ornithogenic landforms appear to be more stable with respect to cryoturbation, and less prone to freezing-and-thawing effects, in view of changing surface albedo. Therefore, birds prefer stable sites for nesting, and once established, theses sites become even more stable, and less subjected to periglacial erosion, due to enhanced, local soil formation and "buffering" organic matter accumulation.

In upland, well-drained areas, such as felsenmeers and compared with other ice-free areas of Admiralty Bay. active solifluction slopes, where wind action is severe and water availability is lower, there is a sparse dominance of crustose and fruticose lichens, mainly Usnea aurantiaco-atra (Jacq.) Bory, near Skuas nests. These areas are less vulnerable than more closelyvegetated Usnea areas, but highly valued due to their degree of endemism. In wet areas, such as lower marine terraces, bryophytes (moss turfs) are widespread. Stable sites near the coast are the preferred areas where Deschampsia antarctica and Colobanthus quitensis develop, in close association with bryophytes and fruticose lichens (Figure 2). Coastal areas devoid of vegetation (beaches, fluvio-glacial plains) are not as valued as others with greater vegetation development (Holocene Terraces, Penguin Rookeries borders, Phosphatized terraces with Deschampsia).

Near the coast, the most complex community occurs on well-drained tops of rocky outcrops, by the combined feedbacks of ornithogenic and landform stability, as previously discussed. There, nitrofilic (ornithocoprophilous) lichen communities, are easily observed by the attractive reddish/yellowish colors of rock outcrops, such as Caloplaca regalis (Vain.) Zahlbr, and Xanthoria elegans (Link.) Th. Fr.

Table 1 Vulnerability and valuation assessment.

\section{Geoenvironment}

Talus

Beaches

Cianobacterial mats

Non-vegetated slopes

Fluvio-Glacial plains with mosses

Penguin Rookeries

Not-vegetated fluvio-glacial plains

Not-vegetated moraines

Holocene terraces with mosses and

Deschampsia sp.

Rock outcrops with nitrophilic lichens

Prasiola Crispa mats around penguin rookeries

Protalus with Deschampsia sp. and mosses

Rock outcrops with Usnea sp. and crustose

lichens

Phosphatized marine terrace with

Deschampsia sp.

Elephants seal nests

Felsenmeer with skuas nests

Former penguin rookeries with ornithogenic

soils and abundant mixed vegetation

Ill-drained ornithogenic areas with mosses

Patchy vegetated slope

Solifluction slopes

Snow bank

Ecology Glacier

Vulnerability Valuation

2

3

4

1

5

5

3

2

4

5

4 5

\section{1}

3

3

1

4

5

2

2

5

4

3

4

5

4

5

5

5

5

4

2

1
Rationale

Areas stabilized for rocky fragments

Corridors for faunal access to coastal area

Plant community highly dependent of waterlogging; eutrophication risk.

Without evaluation

Low tolerance to trampling

Sites of Reproduction / nesting areas

Active sedimentation

Recent exposition of the ground

Low tolerance to trampling

Difficult access area highly vulnerable to human (collecting; trampling)

Rapid recover after abandonment

Stable areas, with little tolerance to trampling Difficult access area highly vulnerable to human (collecting; trampling)

Average sensitivity to the trampling

Reproduction nesting areas

Reproduction nesting areas

High diversity and biomass areas (Deschampsia

sp., lichens, mosses and Colobanthus)

Little tolerant the trampling

Area of primary succession

Active solifluction

Without evaluation

Without evaluation 


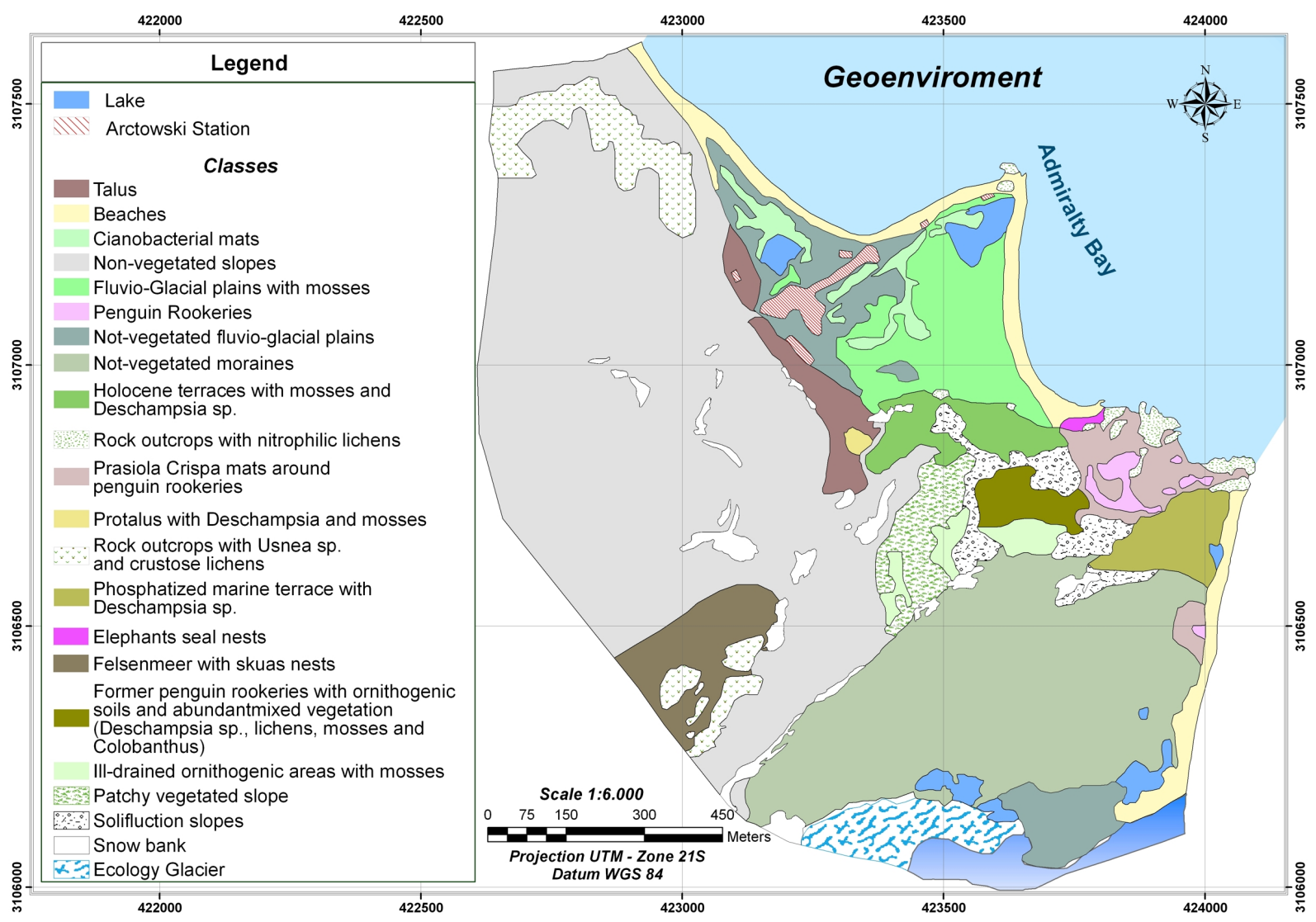

Figure 2. Geoenviromental map of Arctowski Vicinity.

Acknowledgments. We thank the Brazilian Antartic Program (PROANTAR) and Ministry of Science and Technology (CNPq and MMA) for financing the Project (CNPq 550368, Cryosols of Maritime Antartica). Logistical support from the Brazilian Navy to undertake the field work, flights and photograph cover of Admiralty Bay are greatly appreciated. Thanks are extended to Prof. Liovando Costa and Carol Finn who have kindly reviewed the manuscript.

\section{References}

Cooper, A and Murray, R. (1992) A structured method of landscape assessment and countryside management. Applied Geography, 12, 319-338.

Crofts, R.S. and Cooke, R.U. (1974) Landscape Evaluation: A comparison of techniques. Occasional Papers, no 25, Department of Geography, University College London.

Daniel, T.C. and Vining, J. (1983) Methodological Issues in the Assessment of Landscape Quality. In Behaviour and the Natural Environment (eds. Altman, I. and Wohwill, J.),Chapter 2, 39-83, Plenum Press.

Dearden, P. (1985) Philosophy, theory, and method in landscape evaluation. Canadian Geographer, 29, 263-265.

Orland, B., Weidemann, E., Larsen, L. and Radja, P. (1995) Exploring the relationship between visual complexity and perceived beauty. Imaging Systems Laboratory, Department of Landscape Architecture, University of Illinois at Urbana-Champaign. Internet page: http://imlab9.landarch.uiuc.edu/projects/compleximages/complexity.ht $\mathrm{ml}$.

Rakusa-Suszczewski, S. The maritime Antarctic coastal Ecosystem ofAdmiralty Bay. Department of Antarctic Biology, Polish Academy of Sciences, Warsaw, 216 p.1993.

Santana, R. M. Mapeamento de geounidades do meio físico e biótico em área da antártica marítima. Tese de Doutorado, Viçosa, UFV. 174p. 2006.
Schaefer, C. E. G .R.; Pereira, A. B.; Francelino, M. R.; Fernandes Filho, E.I.; Simas, F. N. B.; Costa, L .M. \& Oliveira, A.C. 2004. Comunidades vegetais na Península Keller: ecologia e padrões de distribuição In Schaefer, C.E.G.R., Francelino, M.R., Simas. F.N.B.; Albulquerque Filho, M.R. eds. Ecossistemas Terrestres e Solos da Antártica Marítima, 65-72.

Tatur, A.; Myrcha, A.; Ornithogenic Soils. In: S. Rakusa-Suszczewski (ed.) The Antarctic Coastal Ecosystem of Admiralty Bay. Polish Academy of Sciences, Warsaw. p.161-165. 216p. 1993.

Walton, D.W.H. 1984. The terrestrial environment. In: Laws, R.M. Antarctic Ecology. London: Academic Press. v.1, 1-60.

Zarycky, K. 1993. Vascular plants and terrestrial biotope. In:RakusaSuszcczewski, S. The Maritime Antarctic Coastal ecosystem of Admiralty Bay. Warsaw: Polish Academy of Sciences. 181-189. 